\title{
Retracted: The Genomic and Pathogenic Characteristics of the Highly Pathogenic Porcine Reproductive and Respiratory Syndrome Virus Isolate WUH2
}

\author{
ISRN Virology \\ Received 25 February 2014; Accepted 25 February 2014; Published 1 June 2014 \\ Copyright (C) 2014 ISRN Virology. This is an open access article distributed under the Creative Commons Attribution License, which \\ permits unrestricted use, distribution, and reproduction in any medium, provided the original work is properly cited.
}

The paper titled “The Genomic and Pathogenic Characteristics of the Highly Pathogenic Porcine Reproductive and Respiratory Syndrome Virus Isolate WUH2" [1], published in ISRN Virology, has been retracted as it was submitted for publication by the author Bin Li without the knowledge and approval of the coauthor Shaobo Xiao.

\section{References}

[1] B. Li, L. Fang, S. Liu, Y. Jiang, H. Chen, and S. Xiao, "The genomic and pathogenic characteristics of the highly pathogenic porcine reproductive and respiratory syndrome virus isolate WUH2," ISRN Virology, vol. 2014, Article ID 624535, 15 pages, 2014. 